\title{
CHROMOSOMES AND Ag-NOR LOCATION IN FLUVIATE POPULATIONS OF SALMO TRUTTA FARIO L. 1758 (SALMONIFORMES: SALMONIDAE) FROM ATACAMA DESERT, CHILE
}

\author{
CROMOSOMAS Y LOCALIZACION DE Ag-NOR EN POBLACIONES \\ FLUVIALES DE SALMO TRUTTA FARIO L. 1758 (SALMONIFORMES: \\ SALMONIDAE) DEL DESIERTO DE ATACAMA, CHILE
}

\author{
Irma Northland-Leppe ${ }^{1 *}$, Natalia Lam $^{2}$, Pedro Jara-Seguel ${ }^{3} \& \dagger J_{\text {Juana Capetillo-Arcos }}^{1}$ \\ ${ }^{1}$ Departamento Biomédico, Facultad de Ciencias de la Salud, Universidad de Antofagasta, \\ Casilla 170, Antofagasta-Chile. e-mail: inorthland@yahoo.com \\ ${ }^{2}$ Programa de Genética Humana, Facultad de Medicina, Universidad de Chile, Casilla 70061, Santiago-Chile. \\ ${ }^{3}$ Escuela de Ciencias Ambientales, Facultad de Recursos Naturales, Universidad Católica de Temuco, \\ Casilla 15-D, Temuco-Chile.
}

\begin{abstract}
Salmo trutta fario L. 1758, presented a chromosome number $2 \mathrm{n}=80$ and a fundamental number NF $=100$. The haploid chromosome set consists of seven metacentric chromosomes, three submetacentric, one subtelocentric and 29 telocentrics. The Ag-NOR are located at conserved position in the short arm of pair 11 (st), with the presence of additional NOR on the short arm of pair $9(\mathrm{sm})$ which is rare in others taxa previously studied.
\end{abstract}

KEYwords : Salmo trutta fario, Chromosomes, Atacama region, Chile.

\section{RESUMEN}

Salmo trutta fario L. 1758, presenta un número cromosómico $2 \mathrm{n}=80$ y un número fundamental $\mathrm{NF}=100$. El juego cromosómico haploide está constituido por siete cromosomas metacéntricos, tres submetacéntricos, un subtelocéntrico y 29 telocéntricos. Los Ag-NOR se localizan en posición conservada en el brazo corto del par 11 (st), con la existencia de NOR adicionales en el brazo corto del par $9(\mathrm{sm})$ el que es poco frecuente en otros taxa previamente estudiados.

Palabras clave: Salmo trutta fario, Cromosomas, Región Atacama, Chile.

Chromosomal studies carried out on Salmonidae have constituted an important step to investigations on genetic variation, phylogeny, taxonomy and evolution, as well as to the analysis of the structure, dynamic and diversity of their genomes. At present, the number of contributions on chromosomes for Salmonidae overtake one-hundred publications, thus constituting a robust framework utile for biosystematics studies and for genetic manipulation (Hartley \& Horne 1984, Hartley 1987, Phillips \& Ráb 2001, Hulata 2001). In the case of Salmo trutta L. 1758 an ubiquitous members of the family, numerous investigations on chromosome number, karyotype morphology, Ag-NOR bearing, restriction enzymes, C-banding and CMA3 fluorescence have been documented, although all the studies have been carried out in north hemisphere taxa including natural populations and hatchery stocks (Nygren et al. 1971, Capanna et al. 1973, Zenzes \& Voiculescu 1975, Raicu \& Taisescu 1977, Mayr et al. 1986, Sánchez et al. 1990, Sánchez et al. 1991, Martínez et al. 1991, Karakousis et al. 1992, Woznicki \& Luczynski 1997, Woznicki et al. 2000, Reza et al. 2006). It is remarkable that $S$. trutta shows a broad range of variation in chromosome number, fundamental number $(2 \mathrm{n}=78-84, \mathrm{NF}=98-104)$ and 
Ag-NOR location among their subspecies (Zenzes \& Voiculescu 1975, Hartley \& Horne 1984, Mayr et al. 1986, Castro et al. 2001, Reza et al. 2006), which can be attributable to its considerable variability in ecological and geographical patterns (Martínez et al. 1991). Within the species, S. trutta fario is a subspecies introduced in Chile from early 1,900 within a geographical range from $36^{\circ} \mathrm{S}$ to $56^{\circ} \mathrm{S}$ (Soto et al. 2006), although on latter years has colonized freshwater bodies to the north with the existence of marginal populations in rivers of the Atacama Desert. Preliminary chromosome results for Chilean populations of Salmo trutta fario that inhabit in the central zone with humid climates have been communicated at zoological meetings (Iturra et al. 1986), but nothing is known for marginal populations that inhabit in fluviatile environments in northern Chile.

In this study the chromosome complements and Ag-NOR location for two populations of Salmo trutta fario that inhabit in rivers of the Atacama
Desert are shown for the first time.

The specimens were collected in the Loa and Salado rivers near to Chiu Chiu locality $\left(22^{\circ} 20^{\prime} \mathrm{S}\right.$; $\left.68^{\circ} 39^{\top} \mathrm{W}\right)$. In the laboratory, the fishes were injected with colchicine $0.5 \%(\mathrm{p} / \mathrm{v})$ for $12-16$ hours. Later the gills were excised and treated following the protocol described by Bogart (1973) with some modifications (the gill were washed in distilled water, fixed in $50 \% \mathrm{v} / \mathrm{v}$ glacial acetic acid and the epithelial cells were scraped on the slides). Metaphases were obtained by squashing of epithelial gill-cells using a phase-contrast microscope. To study the standard karyotype the chromosomes were stained using $4 \%$ Giemsa in phosphate buffer at $\mathrm{pH}$ 7.2. Metaphases were photographed with an optical photomicroscope Leitz Laborlux 12. The chromosomes were measured in photographic enlargements and standardized as a percentage of the total haploid set length. The karyogram was made up with the chromosomes paired on the basis of shape and size, and ordered following the

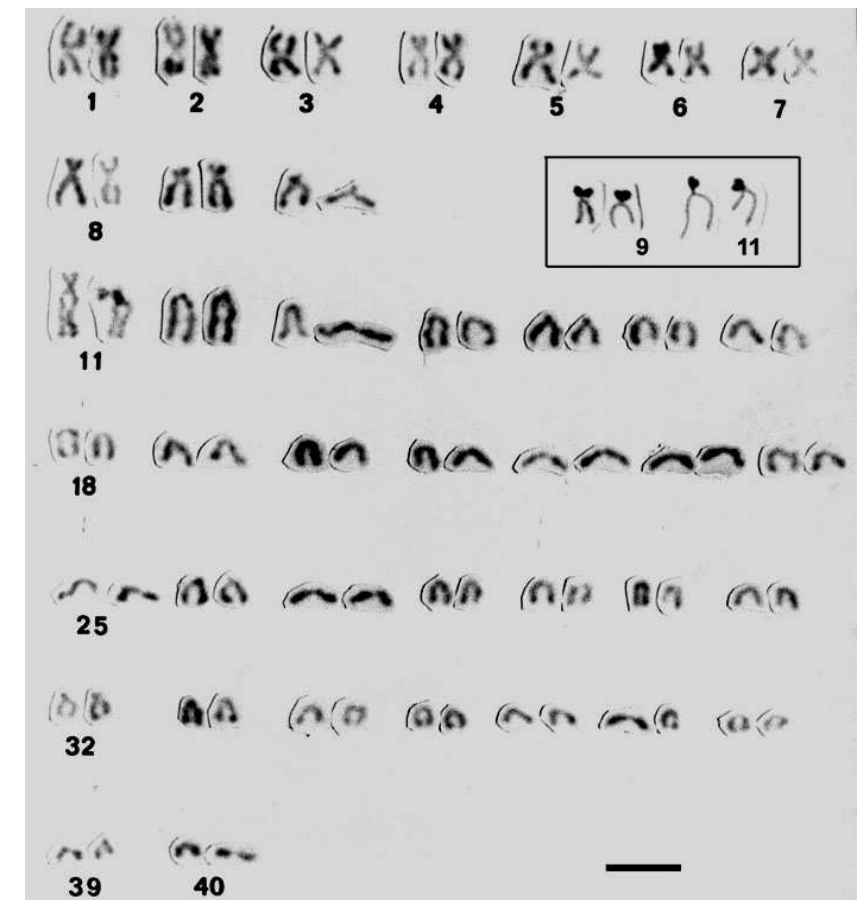

FIgURE 1. Kariogram of Salmo trutta fario, $2 \mathrm{n}=80(\mathrm{FN}=100)$. The inserted square shows the Ag-NOR location in the short arms of the chromosome pairs 9 and 11 . The chromosomes of the haploid set are: seven metacentric ( 1 to 7$)$, three submetacentric ( 8 to10), one subtelocentric (11) and 29 telocentric (12 to 40). Bar $=5 \mu \mathrm{m}$.

FiguRa 1. Cariograma de Salmo trutta fario, $2 \mathrm{n}=80$ ( $\mathrm{FN}=100)$. El cuadro inserto muestra la localización de los Ag-NOR en los brazos cortos de los pares cromosómicos 9 y 11. Los cromosomas del juego haploide son: siete metacéntricos (1 al 17), tres submetacéntricos (8 al 10), un subtelocéntrico (11) y 29 telocéntricos (12 al 40). Barra $=5 \mu$ m. 
categories proposed by Levan et al. (1964). To study NOR location in the chromosomes, the silver nitrate staining method was performed according to the technique described by Sánchez-Rufas et al. (1982). The chromosome number for both Chilean fluviatile populations of $S$. trutta fario from Atacama Desert was $2 n=80$ (Fig. 1) showing similitude with those number previously documented for Romania and Poland populations (Raicu \& Taisescu 1977, Woznicki et al. 1997), as well as for other subspecies from north hemisphere (Karacousis et al. 1992, Reza et al. 2006). Nevertheless, some variations have been observed regarding to fundamental numbers and karyotype formulas among the subspecies (Reza et al. 2006). Several authors have discussed such variations in fundamental number pointing out aneuploidization mechanisms or technical artefacts (Capanna et al. 1973, Raicú \& Taisscu 1977), whereas other have justify the real existence of polymorphism based in the occurrence of Robertsonian traslocations (Zenzes \& Voiculescu 1975, Hartley \& Horne 1984) or modifications in short arm lengths of those NOR chromosomes carrier (Martínez et al. 1991). For Chilean populations of $S$. trutta fario the fundamental number was $\mathrm{FN}=100$, being within the range described for north hemisphere populations whose fundamental numbers documented are 100, 102 and 104 (Raicu \& Taisescu 1977, Woznicki et al. 1997, Woznicki et al. 2000). On the other hand, the haploid karyotype formula for Chilean S. trutta fario was $7 \mathrm{~m}+3 \mathrm{sm}+1 \mathrm{st}+29 \mathrm{t}$, showing resemblance with Poland populations whose formula was $7 m+4 s m+29 s t / t$. It is remarkable that all the complements described within S. trutta are asymmetric with most of $70 \%$ of the chromosomes within the subtelocentric and/or telocentric categories, tendency broadly described in Salmonidae (Phillips \& Ráb 2001).

Large Ag-NOR were observed on the short arms of both homologous of the chromosome pairs 9 (sm) and 11 (st) in the two populations of $S$. trutta fario studied in this work (Fig.1, see inserted square). Such signals were coincident with one and two nucleolus observed in interphase nuclei (data not shown). Previous studies in $S$. trutta have showed that the NORs are located in both homologous of the chromosome pair 11 and in one homologous of the pair 14, although variation in NOR size and in the number of active NORs per genome has been reported ((Mayr et al. 1986, Martínez et al. 1991). Interesting polymorphism with 13 active and stable telomeric NORs has been described for Spain populations of $S$. trutta, thus suggesting that transposition phenomenon responsible for NOR jumping could be still active (Castro et al. 2001). In the present work a relative conservationism in chromosome number and karyotype morphology was demonstrated for populations of $S$. trutta fario from northern Chile, being similar to other populations from north hemisphere. Nevertheless, although NOR location described here for $S$. trutta fario is conservative in the chromosome pair 11, an additional NOR in the chromosome pair 9 is an uncommon feature in other taxa. Further studies in S. trutta fario using cytological techniques widely performed in other subspecies (e.g., C-banding, CMA3 fluorochrome) are necessary to be done, thus increasing the antecedents to evaluate possible karyological variation or stability throughout its wide distributional range in Chile.

\section{BIBLIOGRAPHY}

Bogart, J. 1973. Method for obtaining chromosomes. Caldasia 11(52): 29-40.

Capanna, E., S. Cataudella \& T. Gentile De Fronza. 1973. Some remarks on the karyotype of an intergeneric hybrid, Salmo trutta x Salmo fontinalis (Pisces: Salmoniforms). Genetica 44: 194-206.

Castro, J., S. Rodriguez, B. Pardo, L. Sanchez \& P. Martinez. 2001. Population analysis of an unusual NOR-site polymorphism in brown trout (Salmo trutta L.). Hereditas 86: 291-302.

Iturra, P., R. Moreno \& A. Veloso. 1986. Variación cromosómica en truchas de Chile Central. X Congreso Latinoamericano de Zoología. p. 137.

Karakousis, M., J. Paschos \& C. Triantaphyllidis. 1992. Chromosomal studies in Brown trout Salmo trutta L. populations. Cytobios 72: 266-269.

Hartley, S. \& M. Horne. 1984. Chromosome relationships in the genus Salmo. Chromosoma 90: 229-237.

HaRtLEy, S. 1987. The chromosomes of salmonid fishes. Biological Review 62: 197-214.

Hulata, G. 2001. Genetic manipulation in aquaculture: a review of stock improvement by classical and modern technologies. Genetica 111: 155-173.

Martínez, P., A. Viñas, C. Bouza, J. Arias, R. Amaro \& L. SÁNCHEZ. 1991. Cytogenetical characterization of hatchery stocks and natural populations of Sea and Brown trout from northwestern Spain. Heredity 66: 9-17.

MAYR, B., P. RAB \& M. KALAT. 1986. Localisation of NORs and counterstain-enhanced fluorescence studies in Salmo gairdneri and Salmo trutta (Pisces, 
Gayana 73(1), 2009

Salmonidae). Theorethical Applied Genetics 71: 703-707.

Nygren, A., B. Nilssson \& M. JahnKe. 1971. Cytological studies in Salmo trutta alpinus. Hereditas 67: 259-268.

Phillips, R. \& P. Ráb. 2001. Chromosome evolution in the Salmonidae (Pisces): an update. Biological Review 76: 1-25.

RaICU, P. \& E. TAISESCU. 1977. Cytogenetic study in Salmo irideus and Salmo trutta fario. Cytologia $42: 311$ 314.

Reza, M., S. Dorafshan, T. Tavakolian, M. Khazab \& H. Abdolhay. 2006. Karyological analysis of endangered Caspian salmon Salmo trutta caspius (Kessler, 1877). Aquaculture Research 37: 13411347.

Sánchez-rufas, J., P. Iturra, W. De Souza \& E. Esponda. 1982. Simple silver staining procedures for the location of nucleolus and nucleolar organizer under light and electron microscopy. Archive Biology 93: 267-274.

Sánchez, L., P. Martínez, P. Viñas \& Bouza. 1990. Analysis of the structure and variability of nucleolar organizer regions of Salmo trutta by C-
$\mathrm{Ag}$ and restriction endonuclease banding. Cytogenetic Cell Genetic 54: 6-9.

Sánchez, L., P. Martinez, C. Bouza \& A. Viñas. 1991. Chromosomal heterochromatin differentiation in Salmo trutta with restriction enzymes. Hereditas 66: 241-249.

Soto D., I. Arismendi, J. González, J. Sanzana, F. Jara, C. Jara, E. Guzman \& A. Lara. 2006. Southern Chile, trout and salmon country: invasion patterns and threats for native species. Revista Chilena de Historia Natural 79: 97-117.

WozNICKI, P. \& M. LuCZYNSKI. 1997. Chromosome studies in Salmo trutta m. fario from Poland: Hypothetical evolution of the $11^{\text {th }}, 12^{\text {th }}$ and $14^{\text {th }}$ chromosome pairs in the Salmo karyotype. Cytobios 91: 207-214.

Woznicki, P., L. Sanchez, P. Martinez, B. Pardo \& M. JANKUN. 2000. A population analysis of the structure and variability of NOR in Salmo Trutta by Ag, CMA3 and ISH. Genetica 108(6): 113-118.

ZENZES, M. \& I. VoICULESCU. 1975. C-banding patterns in Salmo trutta, a species of tetraploid origin. Genetica 45: 531-536. 